\title{
Developing an Audiobook for Listening Courseware
}

\author{
https://doi.org/10.3991/ijet.v16i07.21199 \\ Novi Eka Susilowati ${ }^{\bowtie}$, Ariva Luciandika, \\ Dewi Ariani, Martutik \\ Universitas Negeri Malang, Malang, Indonesia \\ novi.eka.fs@um.ac.id
}

\begin{abstract}
This study aims to develop an audiobook for learning listening to students. This research was conducted using the Borg \& Gall development method, with several adjustments for research needs. The research stages carried out were (1) preliminary studies, (2) planning, (3) product development, (4) product validation, (5) first stage revision, (6) product testing, (7) second stage revision, and (8) dissemination. Some innovations are integrated into this book that was developed. This innovation is in the form of integrating theory and listening to various types of texts, from conversational texts to narrative texts. The product developed is listening courseware, which is presented in a flash application. The results showed that the products developed were in accordance with the student needs and could increase student independence. The results of validation tests and trials show that the product developed is feasible to be implemented with an average percentage of the assessment results of $90.71 \%$.
\end{abstract}

Keywords-Audiobook, listening learning, blended learning, listening courseware, technology

\section{Introduction}

All students majoring in Language are required to learn and master four language skills, namely listening, speaking, reading, and writing. Of the four language skills, listening is a skill whose implementation of learning often runs less than ideal. Listening skills often get little attention from teachers in secondary schools [1] [2]. Even, listening skill has been an under-emphasized skill in classrooms, especially in many English as a Second Language (ESL) classrooms, until recent decades [3]. In fact, listening skills are more often acquired outside of the classroom [4]. This results in a lack of listening exposure and student learning autonomy when they study at the University. Even though, listening at a practical level is significant especially with beginner learners [5]. Listening comprehension is difficult for foreign language learners because it is a continuous process that requires learners to understand messages while listening to them and sometimes can lead to a heavy cognitive load [6].

So far, most listening learning has been carried out by delivering listening material directly (for example, lecturers/students listening materials) or indirectly (for example, 
using audio material available on the internet). Unfortunately, these deliveries sometimes experience problems. For example, the listening material that is delivered directly has problems if the lecturer cannot deliver the listening material, then the students are asked to submit it. This resulted in students not participating in the learning to listen to their full potential because when they read the listening material, they did not listen, but read. This is in line with the findings of Mackay [7], which states that learning to listen sometimes becomes learning to read.

The delivery of the listening material through audio devices also has problems because not all classes are equipped with adequate audio players. On the other hand, based on observations of classroom learning in the listening subject, it can be found that the media used still seems monotonous, for example listening to songs and listening to the news. The learning that seems monotonous makes students feel bored and not motivated to think more creatively.

Based on these facts, it is necessary to have an innovation for listening learning, which is expected to be one of the solutions in overcoming problems faced by lecturers in class. Teachers need to design accurate activities to facilitate the practice of the listening skills, based on students' knowledge about the characteristics of the informal oral English language, to help students succeed in their learning [8]. Moreover, communication and information technology are currently developing very rapidly, which can be used to create more creative learning innovations. The use of technology has become an important part of the learning process in and out of class [9]. Thus, listening learning is expected to run optimally.

Listening is part of a multimodal process where all senses participate [10]. Also, listening is mental activity to receive and process all information through listening aids or the sense of listening [11]. That is why listening is said to be a form of active-receptive language skills. It is said to be active-receptive because when listening, there is an activity that occurs in the brain is receiving the impulses that are conveyed in the listening material.

There are eight processes in listening activities [12]. First, the listener processes raw speech in the form of phrases, keywords, intonation, and word stress and stores them in short term memory. Second, the listener determines the type in each speech event that is being processed. Third, listeners seek the intent and purpose of the speaker by considering the form and type of speech, context, and content. Fourth, listeners recall background information in accordance with the context of the existing problem subject. Fifth, the listener looks for the literal meaning of the message he hears. Sixth, the listener determines the intended meaning. Seventh, listeners consider whether the information they receive should be stored in their memory or delayed. Eighth, the listener deletes the messages he has received.

Language has two functions, namely transactional and interactional functions [13]. In connection with the first function, it appears that Language is used by the speaker to convey information, messages, or ideas to the listener. Therefore, Language is utilized in such a way that listeners can receive information, messages, or ideas conveyed by the speaker. That is why listening activities is successful if the information, messages, or ideas conveyed by the speaker are captured equally by the listeners. 
In connection with listening activities, the transactional function of Language brings consequences for the division of types of listening, as suggested by Nunan [5]. Nunan divides listening into two categories, namely monologues and dialogue. Monologue listening means that listening is one-way and does not require reciprocal communication. Meanwhile, listening to dialogue means that listening is two-way and requires mutual communication.

At a higher stage, a person's listening skills are characterized by their ability to inform their understanding again through productive language skills, namely speaking and writing skills [14]. Moreover, listening skills are receptive skills so that to find out one's mastery of the subject matter, it is necessary to test it through other language skills. In listening to activities, there are several things that must be considered in relation to language learning, listening situations, and class activities [15]. Listening to Language in a particular context requires the teacher/lecturer to carefully examine the use of spoken texts in various oral situations. Therefore, learning activities can be planned and sequenced in such a way that listening tasks can be linked to certain situations or real situations to improve students' ability to understand conversations or texts in real conditions.

So far, many ideas that are listening are a means of mastering other language skills. Listening is one of the skills in language teaching that should be taught before speaking, reading, and writing [16]. However, listening is at the same level as other language skills [15]. Therefore, the four must be taught simultaneously, or at least other language skills can be used to measure the level of one language skill.

In learning language skills, including learning listening skills, learning input is obtained from controlled and planned language examples to form a language system in the learner's mind. From this thought, it appears that learning media is needed that provides examples of listening materials that can be well received by students. One of the factors that may affect the success of the learning process is the use of learning media [17]. Therefore, innovation in developing learning media for listening is relevant to do.

Many previous researchers have developed learning media for listening courses. The development of instructional media for listening courses has been done by many previous researchers. Previous researchers have developed audio [18] [19] [20] and video [21] [22] [3] for listening learning. The results of these studies indicate that audio media can improve students' listening ability when compared to without media. However, the findings of Rahmatian \& Novid; Yasin, et al; and Choo \& Yunus show that the use of audio and video media is the best in improving students' listening skills.

However, the media developed has not fully provided the desired results because in the learning media that have been developed there are still shortcomings. First, the media being developed are made separately from the learning material. It is very important to present learning materials that are directly embedded in the learning media. Second, most of the media developed so far are partial, meaning that they only relate to one learning material. Students need to learn more material that is presented in the learning media. Based on these facts, it is necessary to have an innovative listening learning media that can attract students to learn and is assumed to be a solution to the obstacles that have been encountered so far. 
The results of the preliminary analysis show the following findings. First, students need innovative learning media so that their learning motivation in the listening subject can increase. Second, students need learning media that they can use independently. Moreover, learning nowadays is no longer limited to classrooms and learning can be done anywhere and anytime. Third, students need learning media that is directly related to the learning material presented in one book. That is, learning media is presented in a book in which there is learning material because so far learning media is presented separately from learning material. In fact, listening theory books have not been equipped with listening material. If it is also equipped with listening material, the listening material is presented separately as an attachment.

Based on the facts that have been stated, one way to overcome the problems as stated above is to make an audiobook media for listening learning. Audiobook can make it easier for lecturers to teach listening subjects. It is in line with what Ramirez as stated Potosi, et al. [23] stated that anything used in a class, is a meaningful tool to facilitate the learning of a language. Lecturers no longer have to read the book that they want to examine, but students just need to open the book they want and the book can output its audio. The audiobook also includes listening learning material that is directly linked to listening practice and practice questions. Thus, it contains material as well as listening material which is not found in listening learning media that have been developed so far.

The application of the audiobook is expected to make the learning of listening more interesting, effective, and efficient so that students are more enthusiastic in the learning process. The development of this learning innovation resulted in a product in the form of an audiobook for listening learning. This audiobook can be accessed by lecturers and students (students) because the audiobook and learning tools are uploaded in e-learning. This audiobook can also be used independently by students because the listening materials are presented linearly with the learning material presented, and the listening materials are integrated with the learning material.

\section{$2 \quad$ Method}

\subsection{Product development stage}

This development research uses the Borg \& Gall development model. However, for the purposes of this study, the researcher made some adjustments so that not all stages of the research of the Borg \& Gall model were carried out. The research on the development of this audiobook was carried out in only eight stages, namely (1) preliminary study, (2) product design, (3) product development, (4) product validation, (5) first stage revision, (6) product testing, (7) second stage revision, and (8) dissemination. The stages of developing an audiobook, as stated, are illustrated in Figure 1. 


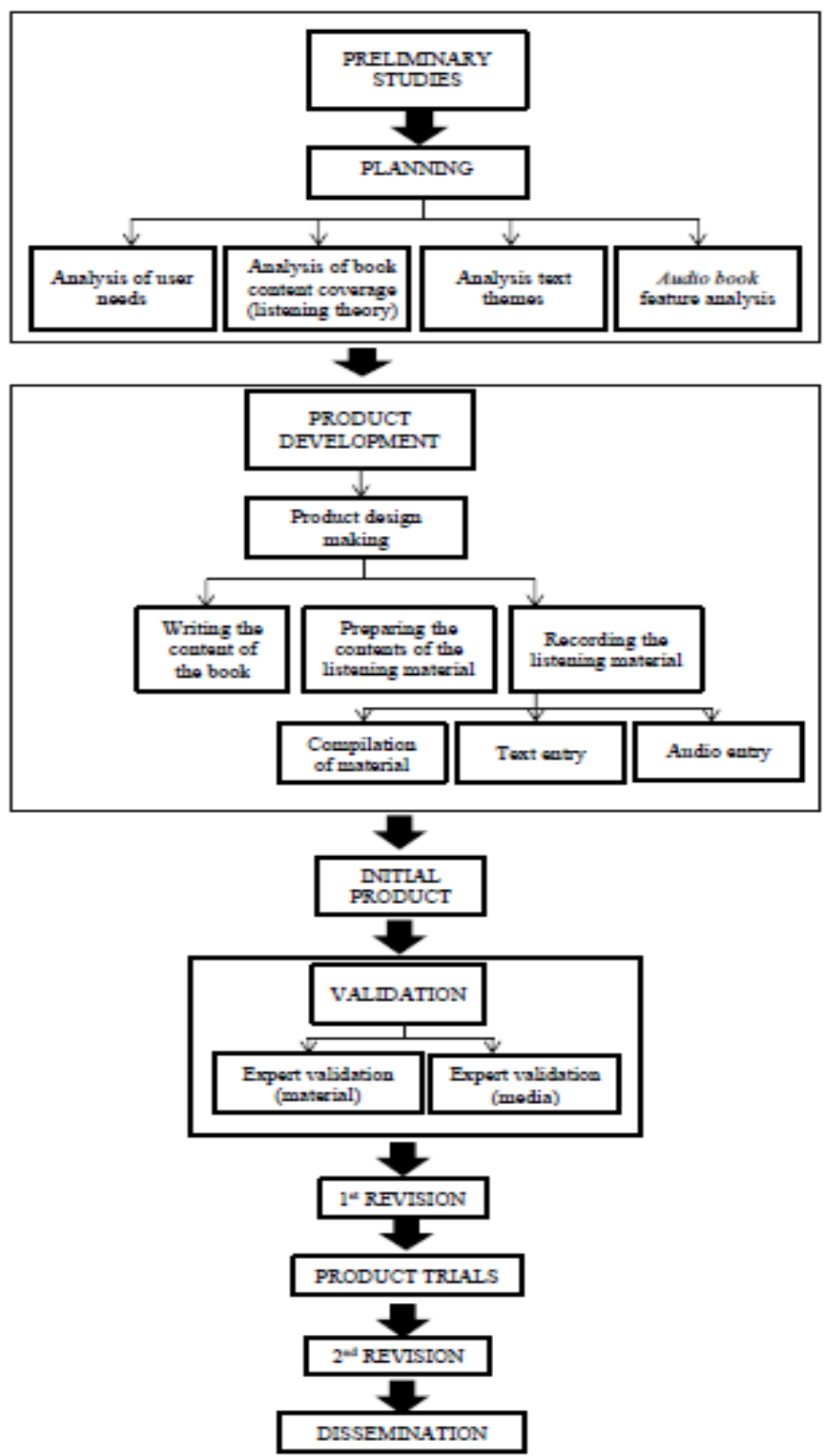

Fig. 1. Product Development Stage

The first stage, a preliminary study. The preliminary study was carried out by collecting information about the implementation of listening learning so far in class. This preliminary study was also conducted to identify problems that occurred in the listening learning class. Based on the results of the preliminary study, it can be found that listening learning carried out in the Indonesian Literature Department, Faculty of Letters, 
Universitas Negeri Malang, is still quite monotonous because it uses listening material from (1) reading texts by lecturers/students, (2) playing songs, (3) digital audio or audiovisual playback taken from digital sources, and (4) listening material that is not integrated with listening learning material. Based on these findings, it is necessary to develop a product to help overcome these problems.

The second stage, product planning. Product design activities include (1) user needs analysis, (2) material content analysis (listening theory), (3) analysis of text themes, and (4) analysis of features that will be integrated into the audiobook. User needs analysis is used to explore information about the product description that users need in carrying out listening learning. Analysis of material content is used to determine what material will be presented and to what extent the scope of the material is presented. Analysis of text themes is used to find out what themes are relevant to be presented in the audiobook. Feature analysis is used to dig up information about what features are suitable and relevant to be presented in the audiobook.

The third stage, product development. Product development activities are carried out in the form of (a) writing the contents of the book, (b) preparing the contents of the listening material, (c) recording the listening material. Book writing is done by reading, studying, and comparing other listening materials to be elaborated with the writer's thoughts. The ideas obtained from the listening materials are used as a support, contrast, and comparison of the writer's ideas. What is not important is that the book is written is in accordance with the listening learning theory. Relevance relates to the validity of the content [24].

The preparation of the listening material is done by writing the contents of the listening material according to the theme and type of text. The theme of the material is in the form of character education and the environment. The types of text to be developed are conversational text and narrative text. This listening material is then recorded to be integrated into the compiled book.

After the listening material is prepared in written form, the next step is to record the listening material. The recording of the material is done in a recording studio and done by a team of experts. This is intended to get good audio listening material. The listening material is recorded using a narrator with predetermined criteria, as stated in the previous section. To produce good audio, too, the recordings are processed by eliminating sound distractions so that the resulting audio is truly clear and suitable for use as a listening medium. After the audio is ready, the audio is integrated into the book that has been written.

The fourth stage, validation. The validation carried out includes two kinds of validation, namely material and media validation. Material validation is carried out to language skills learning experts, while media validation is carried out to communication and information technology experts, especially technology and communication in the field of learning.

The fifth stage, the first stage revision. The first stage of the revision is carried out after the product is validated. Products that have been validated receive ratings, comments, criticism, and suggestions from the Validator. Ratings, comments, criticisms, and suggestions from this Validator are used as material for making product revisions. 
The sixth stage, product testing. Product trials were carried out to determine the level of readiness of the audiobook that was developed to be implemented in real terms in learning. At this stage, the audiobook that was returned was developed for ratings, comments, criticisms, and suggestions from the test subjects.

The seventh stage, the second stage of product revision. The second stage of product revision is carried out after the product being developed receives an assessment from the test subject. This revision was made so that the product being developed was more perfect.

The eighth stage, dissemination. Product dissemination is carried out by publishing product development results through scientific publications. Dissemination of research results is also carried out by including research products at the exhibition of innovative products.

\subsection{Data analysis}

Data analysis was carried out by analyzing quantitative data and qualitative data from the results of filling out the questionnaire during product validation and product testing. Quantitative data in the form of scores from the Validator's assessment and the test subjects for the audiobook. The qualitative data in the form of comments, criticisms, and suggestions from the validators and test subjects. The conclusion from the results of data analysis is used as a reference material to determine whether or not a product revision is necessary or the feasibility of product implementation.

Quantitative data analysis was carried out by processing the numerical data on the scores from filling out the validator questionnaire and the test subject questionnaire. The data were analyzed using the following formula.

$$
\mathrm{P}=\frac{\sum x}{\sum x i} x 100 \%
$$

Information:

$\mathrm{P}=$ Percentage

$\sum \mathrm{x}=$ Total number of respondents' answers in all items

$\sum \mathrm{xi}=$ Total ideal score in per item

$100 \%=$ Constant

The results of these calculations produce the percentage of the assessment results. The percentage of the calculation results is used as a reference for determining product criteria. The product criteria are determined based on the scale, as shown in Table 1.

Table 1. Determination of Product Revision

\begin{tabular}{|c|l|}
\hline Percentage Interval & \multicolumn{1}{|c|}{ Follow-Up } \\
\hline $90-100$ & Implementation (I) \\
\hline $70-89$ & Implementation with a minor revision (IR) \\
\hline $50-69$ & Revisions according to expert and practitioner notes (R) \\
\hline$<50$ & Revision by modification (U) \\
\hline
\end{tabular}




\section{$3 \quad$ Result}

\subsection{Product specification}

The development of this learning innovation produces an audiobook. This audiobook is packaged in the form of a reading book which contains integrated listening material. Therefore, lecturers do not need to open other tools or look for listening material from other sources because, in this audiobook, listening material has been provided and is integrated with learning materials.

This audiobook is in the form of a digital book that consists of a beginning, a core, and an end. The initial section contains a cover page, introduction, and table of contents. The core part contains three chapters, namely (1) Chapter 1: Introduction (Bab 1: Pengantar), (2) Chapter 2: Listening to the Conversation Text (Bab 2: Menyimak Teks Percakapan), and (3) Chapter 3: Listening to the Narrative Text (Bab 3: Menyimak Teks Narasi). Chapter 1 contains (a) the nature of listening, (b) types of listening, (c) the purpose of listening, (d) listening learning, and (e) listening learning assessments. Chapter 2 contains (a) descriptions of the material, (b) strategies for listening to conversational texts, and (c) exercises. Chapter 3 contains (a) a description of the material, (b) listening to narrative text strategies, and (c) exercises. The final section contains a list of references.

At the beginning of the book display, there are menus selected by the user. These menus serve to take the user to certain parts that they want to learn. If the user clicks on a menu, the user will go to the desired page.

The listening material in the form of audio in this book is presented in Chapter 2 and Chapter 3, while in Chapter 1, there is no listening material because Chapter 1 contains only theories about listening. The material for observation is placed in Chapter 2 and Chapter 3 because the two chapters specifically discuss listening to certain types of text, namely conversational text, and narrative text. Each type of text is equipped with a listening strategy so that it is easier for students to understand the materials for listening to the two types of text. Furthermore, each listening strategy is complemented by an example of implementing the strategy and listening material for the exercise.

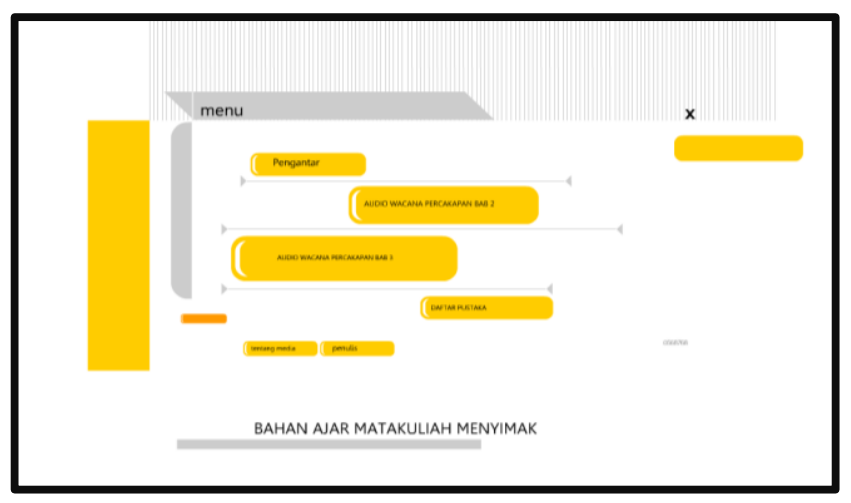

Fig. 2. Audio Book Content Section Views 


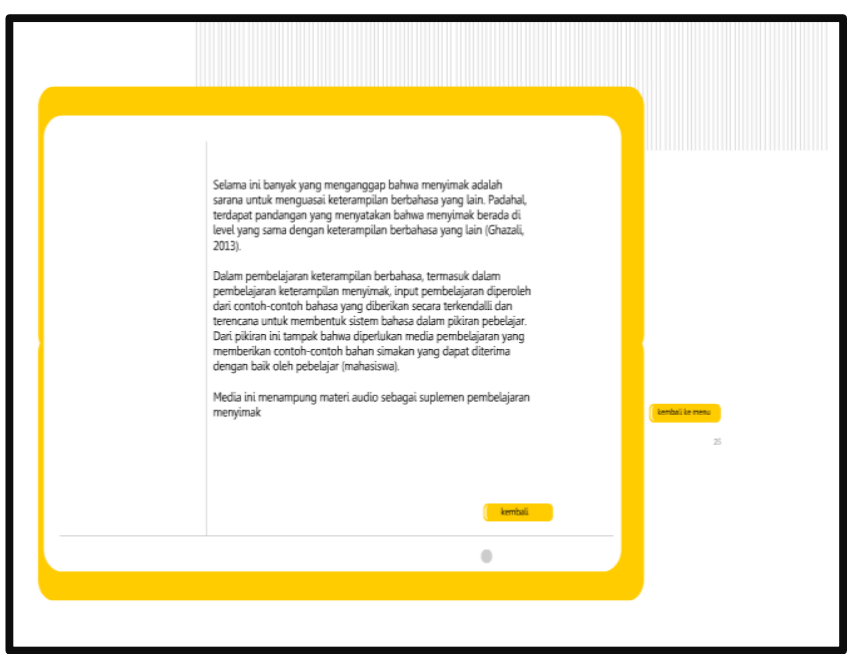

Fig. 3.

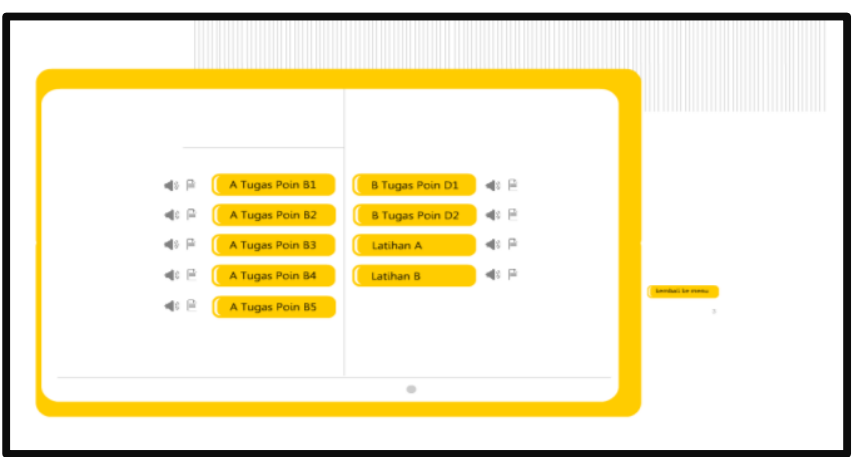

Fig. 4. Audio Section Views

On every page of the audiobook, there is also a Back to Menu (Kembali ke Menu) button. This button serves to direct the user if you want to return to the initial view, which contains menus available in the audiobook.

This audiobook is arranged in digital form and can be duplicated as needed so that lecturers can easily provide copies of books to students. This audiobook can also be used independently by students because the listening material has been integrated into the book. Thus, lecturers no longer have to read or ask certain students to read the texts they want to teach or practice questions because students can do it themselves. However, it would be ideal if the lecturer continued to accompany the use of the audiobook.

The texts in the book are manifested in the form of conversational texts and narrative texts. The conversational text that is entered in the conversation text about everyday life is related to themes, for example, conversations in the context of lectures, friendships, and travel. So, the activities engage students in the use of the target language in the "real world" [25]. The narrative text that is entered is in the form of narrative text 
on topics of health, environment, and social care. The narrative text is between 200-300 words long. The determination of this amount is based on the consideration of the listener's ability to receive the listening material through the audio media device. The length of this text is also related to the ease of product development. The sentences used are mostly simple sentences that make it easier for students to get the contents of the listening material. This is in line with Sporn, et al. opinion that listening material must be well and careful scripting so that it is easy for students to listen [26].

For the text included in the audiobook to be of adequate quality, the researcher must carefully select the text. The selected texts are texts taken from other sources (newspapers, magazines, journals, etc.), which are adapted for learning purposes. To produce good audio quality, a good narrator is chosen, namely a narrator who has good voice quality, clear pronunciation, and can read out the contents of the text with the right intonation. Also, to get good audio quality, distractions that can damage the audio quality are eliminated or minimized.

\subsection{Product validation}

Product validation consists of two kinds of validation, namely material and media validation. Material validation was done by giving fourteen questions to explore the feasibility of the contents of the book. The fourteen questions include (1) the suitability of the material developed with the course description, (2) the accuracy of concepts and definitions, (3) the accuracy of examples and cases, (4) the suitability of language selection with the level of thinking of the reader/user, (5) ease of use. Choice of Language in the material, (6) accuracy of terms used, (7) depth of discussion of material/concepts, (8) completeness of discussion of material/concepts, (9) ability to encourage curiosity, (10) ability to encourage questioning skills, (11) the accuracy of selecting the topic of the material, (12) the ease of understanding the language used in the book, (13) the clutter of logic/reasoning in presenting the material, and (14) the accuracy of logic/reasoning in presenting the material. The fourteen questions were answered with five answer ratings, namely strongly agree, agree, disagree, disagree, and strongly disagree. In addition, the Validator can also provide verbal qualitative input for product improvement.

The results of material validation show that, in general, this book is good and suitable for revision. This can be seen by the number of answers that strongly agree (8 questions) and agree to answers (6 questions) with an average assessment result of $91.42 \%$. However, the Validator also gave suggestions on several parts of the book to be improved. One of them is about the consistency of the use of terms because some terms that are not used consistently, for example, the use of the word mendengar (hearing) and menyimak (listening) even though the word in question is menyimak (listening). In some parts of the book, there are also lines of reasoning that are not coherent. Therefore, the Validator suggests improving the line of reasoning in book descriptions.

Media validation was carried out by giving twelve questions to explore information about the appearance and presentation of the book. The twelve questions include (1) The accuracy of choosing the font type, (2) Proportional selection of the font size, (3) Appropriateness of the book appearance, (4) The attractiveness of the appearance of the 
front and back cover pages of the book, (5) Harmony of color choices, (6) The consistency of the layout between the parts of the book, (7) The harmony of the layout of the book, (8) The completeness of the titles, subtitles, and numbers in the book, (9) The accuracy in using numbering and details in the book, (10) The clarity of the recorded sound (none disturbing noise), (11) Clarity of recorded sound (accuracy and breadth of pronunciation), and (12) Appropriateness of using sound effects. The twelve questions were answered with five answer ratings, namely strongly agree, agree, disagree, disagree, and strongly disagree. The Validator can also provide input for product improvement.

The results of media validation show that the audiobooks are good. The appearance and design of the book are also good. The use of colors that are quite striking also attracts attention so that people want to see the book. Of the twelve questions submitted to the media validator, the answers obtained strongly agree (6 questions) and agree (6 questions) with an average assessment result of $90 \%$. It's just that, according to the media validator, the book design is too small so that the readability is not good. Therefore, the Validator suggested that the book design be enlarged.

The two types of validation that have been carried out have resulted in evaluations and suggestions from the validators for product improvement. Based on the two validation results, the average result of the product appraisal is $90.71 \%$. This means that the product is feasible to be implemented with previous revisions based on comments and input from the validators.

\subsection{Product trials}

Product trials were conducted on twenty students of the Indonesian Department, Faculty of Letters, Universitas Negeri Malang. The twenty students have taken the Comprehensive Listening and Critical Listening courses. The twenty students were chosen because they had already taken the listening course so that they could apply the schemata they have about listening learning in the developed audiobook.

During product testing, students installed the audiobook on their electronic devices (on laptops or gadgets). Furthermore, they operate the audiobook to study the material in the audiobook. After that, they applied the listening material presented in the audiobook. They also work on the available practice questions. In the implementation of the trial, the researcher provided assistance and observation of the activities of the test subjects in using the developed audiobook.

After using the audiobook, the test subjects filled out a questionnaire containing assessments, responses, criticisms, and suggestions of the test subjects regarding the use of the audiobook for listening learning. The questionnaire contains 26 questions relating to aspects of the material content and the appearance of the audiobook. The results of filling out the questionnaire resulted in an average percentage of $88.07 \%$. This result means that the product is feasible to implement with a few revisions. 


\section{Discussion}

It is necessary to develop an audio book to provide complete teaching materials which contain materials, examples and exercises. The provision of complete teaching materials will increase students' learning independence. Moreover, the audio book developed is based on technology that can be operated on various electronic devices so that students can use it anywhere and anytime. In fact, Mohamed's [20] research results show that the use of audiobooks significantly improved listening comprehension among the experimental group. Audio books can make students read the material and listen to the listening material at the same time and the listening material is also linear with the material presented in the audio book.

The results of validation tests and product trials show that the product is suitable for use. The materials presented in the developed audio book are relevant to student needs. Learning materials that are relevant to student needs will increase student learning motivation. This is in line with the results of research by Uenishi [27] and Peacock [28] which state that learning material is closely related to student learning motivation where teaching materials that are in accordance with student needs will motivate students to take part in learning.

The use of technological aspects in the product being developed can also create a learning atmosphere that conditions students to study independently. Thus, student independence can be increased. This independence can also increase students' confidence in learning. This is in accordance with the results of a study which states that Ahmadi [9] when teachers allow learners to become assistants in the teaching process, this can increase learners' confidence. In addition, the use of technology in the product being developed also makes students interested in learning. Baytak, Tarman, and Ayas [29] stated that the use of technology in learning made learners' learning interesting and interactive and increased their motivation, social interactions, and engagement.

In terms of substance, this book presents theories and strategies for listening to various materials. In the listening books that existed before, there were no listening strategies so that readers did not get information about an efficient way of listening to various types of texts. As a result, readers still find it difficult to find the message contained in the reading material. In fact, the listening strategy is important for students to know so that when listening, students can really understand the contents of the listening material. That is why, Arono [30] states that in learning to listen, pre, during, and after listening activities need to be understood. Among the pre-listening activities is understanding the strategies in understanding the contents of the listening material.

In this developed audio book, each strategy of listening to various materials is accompanied by examples of its application. So, students can practice how to use the strategies presented with examples of questions so that students can fully understand the steps for implementing the strategies presented. The results of the validation test show that the provision of listening strategies with listening material makes students feel easy to find the contents of the listening material because the strategy in finding the contents of the listening material is already written in the book and they can learn.

To presenting listening strategies and examples of their application, this book is also equipped with practice questions. This is done so that students can apply the strategies 
presented in real conversational texts so that students' understanding is more complete. So, providing learning resources and various learning experiences can give opportunities to the learners to interact and build knowledge and skills optimally [31].

The exercises presented in this book are in the form of audio materials. Thus, students or lecturers do not need to look for reading material that matches the material presented in the audio book from other sources. Students also no longer need to read reading material so that other students can listen to it. The reading material in this audio book is not equipped with a transcript because it is based on the research results of Chang, et.al. [6], text at listening materials added no benefit to schema construction in long term memory. Kalyuga, Chandler, \& Sweller [32] suggested that some multimedia learning software can lead to cognitive overload, which affects learning performance negatively.

The reading material provided in this book can also be listened to over and over again by students. Playing the listening material repeatedly can also improve students' listening comprehension skills. This is in accordance with research by Nation \& Newton [33] and Mohamed [20] which states that repeated listening to the listening material proved to be useful in improving students' listening fluency. Thus, the results of this study revealed that audiobooks are useful in developing reading comprehension and listening skills among learners [20] [34].

This audio book is packaged in digital form. This makes it easy for lecturers to distribute books and makes it easier for students to carry this book. This audio book supports the implementation of learning anywhere and anytime. Since learners have different educational backgrounds and learning preferences, it is better for learners to learn at their own pace and obtain information they need at any time [35]. In addition, presenting books in digital form also enables students to move quickly across electronic text from one scene to another to build understanding [36].

\section{Conclusion}

There are two conclusions obtained based on the results of research and development. First, the developed audio book is feasible to be implemented in real learning in class. This can be seen from the difficulty of evaluating the validators and the test subjects. Second, the developed audio book can be used independently by students so that students can use this audio book anytime and anywhere. However, even though this audio book can be used independently by students, mentoring from lecturers is still needed, especially in terms of deepening or strengthening theory because a combination of face-to-face and online formats would be a good choice [37].

Based on the results of research and discussion, it can also be concluded that the audio book that was developed is very useful for improving students' listening skills. This audio book is also useful in increasing students' learning independence. However, listening material that can be played over and over again and is not limited can cause students' listening results to be inauthentic. Therefore, for the next development research, it is necessary to present the reference material for questions that can be played in a limited manner. 


\section{References}

[1] R. P. Yaniafari, N. Mukminatien and Y. Basthomi, "Integrating Islamic Knowledge into Multimedia-Based Supplementary Listening Materials," International Journal of Emerging Technologies in Learning (iJET), vol. 15, no. 7, pp. 43-60, 2020. https://doi.org/ 10.3991/ijet.v15i07.13225

[2] N. Kusumadewi and D. Ulhusna, "Ismik (Istima"e Asik) Media Pembelajaran Berbasis Cross Cultural Understanding terhadap Keterampilan Menyimak Bahasa Arab Siswa MTs KELAS VII [Learning Media Based on Cross Cultural Understanding of Arabic Listening Skills for Class VII MTs Students]," in Prosiding Seminar Nasional Bahasa Arab Mahasiswa III Tahun 2019 HMJ Jurusan Sastra Arab Fakultas Sastra Universitas Negeri Malang, Malang, 2019. https://doi.org/10.36722/sh.v2i1.118

[3] Choo, Siang Shian \& Yunus, Melor Md., "Audio Clips in Developing Listening Comprehension Skills in Malaysian Primary ESL Clasrooms," in Proceeding of International Seminar on Generating Knowledge Through Research, UUM-UMSIDA, 25-27 October 2016, Malaysia, 2016. https://doi.org/10.21070/picecrs.v1i1.511

[4] M. F. Litzler, M. H. Jérez and M. Bakieva, "Prior Experience and Student Satisfaction with ETandem Language Learning of Spanish and English," International Journal of Interactive Mobile Technologies (iJIM), vol. 12, no. 4, pp. 4-20, 2018. https://doi.org/10.3991/ijim. v12i4.9196

[5] Nunan, Second Language Teaching and Learning, Cambridge: Cambridge University Press, 1983.

[6] C.-C. Chang, H. Lei and J.-S. Tseng, "Media Presentation Mode, English Listening Comprehension and Cognitive Load in Ubiquitous Learning Environments: Modality Effect or Redundancy Effect?" Australasian Journal of Educational Technology, vol. 27, no. 4, pp. 633-654., 2011. https://doi.org/10.14742/ajet.942

[7] M. Mackay, Literacies Across Media: Playing the Text, London: Routledge Falmer, 2002.

[8] R. W. Norris, "Teaching Reduced Forms: An Aid for Improving Lower-Level Students' Listening Skills," Fukuoka Women's Junior College Studies, vol. 46, pp. 49-56, 1993.

[9] M. R. Ahmadi, "The Use of Technology in English Language Learning: A Literature Review," International Journal of Research in English Education, vol. 3, no. 2, pp. 115-125., 2018. https://doi.org/10.29252/ijree.3.2.115

[10] T. M. Royo and J. G. Laborda, "Binaural Sound to Enhance Listening Comprehension in," International Journal of Interactive Mobile Technologies (iJIM), vol. 14, no. 1, pp. 4-14, 2020. https://doi.org/10.3991/ijim.v14i01.11739

[11] Mudjianto and G. Susanto, Materi Pembelajaran Menyimak [Listening Learning Materials], Malang: A3 (Asah Asih Asuh), 2010.

[12] H. D. Brown, Principles of Language Learning and Teaching, London: Pearson Longman, 2007.

[13] G. Brown and G. Yule, Analisis Wacana [Discourse Analysis]. Terjemahan oleh I. Soetikno., Jakarta: PT Gramedia Pustaka Utama, 1983.

[14] Iskandarwassid and D. Sunendar, Strategi Pembelajaran Bahasa [Language Learning Strategy], Bandung: PT Rosdakarya, 2008.

[15] A. S. Ghazali, Pembelajaran Keterampilan Berbahasa [Language Skill Learning], Bandung: PT Refika Aditama, 2013.

[16] J. D. O'Connor, Better English Pronunciation (Second Edition), New York: University of Cambridge, 1998.

[17] Plomp, T., \& Nieveen, N., An Introduction to Educational Design Research, www.slo.nl/organisatie/international/publications11, 2010. 
[18] Alfian, A. Lio and L. O. S. Marafat, "The Use of Audio Podcast for Teaching Listening Comprehension," Journal of Language Education and Educational Technology, vol. 4, no. 1, p. http://dx.doi.org/10.33772/jleet.v4i1.6671, 2019.

[19] M. S. Astuti, M. Marhum and Erniwati, "Improving Listening Comprehension Skills of The Second Year Students Through Audio-Lingual Method," e-Journal of English Language Teaching Society (ELTS), vol. 4, no. 1, pp. 1-12, 2016.

[20] M. M. K. Mohamed, "Using Audiobooks for Developing Listening," Journal of Language Teaching and Research, vol. 9, no. 1, pp. 64-73. http://dx.doi.org/10.17507/jltr.0901.08, 2018.

[21] R. Rahmatian and A. Novid, "The Effectiveness of Audio and Video Documents in Developing Listening Comprehension Skill in a Foreign Language," International Journal of English Linguistics, vol. 1, no. 1, pp. 115-125, 2011. https://doi.org/10.5539/ijel.v1n1p115

[22] B. Yasin, F. Mustafa and R. Permatasari, "How Much Videos Win Over Audios in Listening Instruction for EFL Learners," TOJET: The Turkish Online Journal of Educational Technology, vol. 17, no. 1, pp. 92-100, 2018.

[23] L. J. A. Potosi, E. A. G. Loaiza and A. C. L. Garzia, "Using Video Materials as a Teaching Strategy for Listening Comprehension," http://recursosbiblioteca.utp.edu.co/dspace/bitstream/11059/1936/1/371333A786.pdf, 2009.

[24] A. T. Ampa, "The Implementation of Interactive Multimedia Learning Materials in Teaching Listening Skills," English Language Teaching, vol. 8, no. 12, pp. 56-62. 2015. https://doi.org/10.5539/elt.v8n12p56

[25] N. Mukminatien, R. P. Yaniafari, T. Kurniawan and A. Wiradimadja, "CLIL Audio Materials: A Speaking Model for Library Science Department Students," International Journal of Emerging Technologies in Learning (iJET), vol. 15, no. 7, pp. 29-42. 2020. https://doi. org/10.3991/ijet.v15i07.13223

[26] Z. Sporn, C. Julia and D. Meehan, "Babbel Language Learning Podcasts," International Journal of Advanced Corporate Learning (iJAC), vol. 13, no. 3, pp. 43-49., 2020. https://doi. org/10.3991/ijac.v13i3.17025

[27] K. Uenishi, "The Usefulness of Original Teaching Materials for Motivation," in The Role of Technology in Education, 2019, pp. https://www.intechopen.com/books/the-role-of-technology-in-education/the-usefulness-of-original-teaching-materials-for-motivation. https:// doi.org/10.5772/intechopen.85440

[28] M. Peacock, "The Eeffect of Authentic Materials on the Motivation of EFL Learner," ELT Journal, vol. 51, no. 2, pp. 144-156, 1997. https://doi.org/10.1093/elt/51.2.144

[29] A. Baytak, T. Bulent and C. Ayas, "Experiencing Technology Integration in Education: Children's Perceptions," International Electronic Journal of Elementary Education, vol. 3, no. 2, pp. 139-151, 2011.

[30] Arono, "Improving Students Listening Skill Through Interactive Multimedia in Indonesia," Journal of Language Teaching and Research, pp. 1-10. 2014. https://doi.org/10.4304/ jiltr.5.1.63-69

[31] Littlejohn, A. \& Pegler, A., Preparing for Blended e-Learning, London: Routledge. Taylor and Francis Group English Teaching, 2007. https://doi.org/10.4324/9780203961322

[32] Kalyuga, S., \&Chandler, P., \& Sweller, J., "Incorporating learner experience into the design of multimedia instruction," Journal of Educational Psychology, vol. 92, no. 1, pp. 126-136. http://psycnet.apa.org/doi/10.1037/0022-0663.92.1.126, 2000. https://doi.org/10.1037/ $\underline{0022-0663.92 .1 .126}$

[33] I. Nation and J. Newton, Teaching ESL/EFL Listening and Speaking, Routledge: Taylor \& Francis, 2009. 
[34] G. Kartal and G. Şimşek, "The Use of Audiobooks in EFL Classes to Improve Reading and Listening Skills," in 2nd International Conference on New Trends in Education and their Implications, Antalya-Turkey, 2011.

[35] J. C. Yang and Y. L. Lin, "Development and Evaluation of An Interactive Mobile Learning Environment with Shared Display Groupware," Educational Technology \& Society, vol. 13, no. 1, pp. 195-207. http://www.ifets.info/download pdf.php?j id=46\&a id=1030, 2010.

[36] P. Gruba, "Playing the Videotext: A Media Literacy Perspective on Video-Mediated L2 Listening," Language Learning \& Technology, vol. 10, no. 2, pp. 77-92. http://llt.msu.edu/ vol10num2/gruba/, 2006.

[37] F. Mishan, "Demystifying Blended Learning," in In Tomlinson, B. (Ed.) Developing Materials for Language Teaching, London, Bloomsbury Publishing, 2013

\section{Authors}

Novi Eka Susilowati, S.Pd., M.Pd. is a lecturer at Indonesian Department, Faculty of Letters, Universitas Negeri Malang. She is teaching Introduction on Linguistics, Indonesian Morphology, Indonesian Syntax, and Indonesian Grammar. She also teaches Indonesian language for foreign speakers, especially for Chinese students. She earned her bachelor and master degree on Indonesian Language Education at Universitas Negeri Malang, Indonesia.

Ariva Luciandika, S.Pd., M.Pd. is a lecturer at Indonesian Department, Faculty of Letters, Universitas Negeri Malang. She is teaching Indonesian Education, Entrepreneurship, Writing, and Indonesian language for foreign speakers. She also teaches Indonesian language for foreign speakers, especially for Chinese students. She earned her bachelor and master degree on Indonesian Language Education at Universitas Negeri Malang, Indonesia.

Dewi Ariani, S.Pd., M.Pd. is a lecturer at Indonesian Department, Faculty of Letters, Universitas Negeri Malang. She is teaching Indonesian Education, Writing, and Indonesian language for foreign speakers. She also teaches Indonesian language for foreign speakers. She earned her bachelor and master degree on Indonesian Language Education at Universitas Negeri Malang, Indonesia.

Dr. Martutik, M.Pd. is a lecturer at Indonesian Department, Faculty of Letters, Universitas Negeri Malang. She is teaching Discourse Analysis and Listening Comprehension. She also teaches Indonesian language for foreign speakers, especially for Chinese students. She earned her bachelor, master, and doctoral degree on Indonesian Language Education at Universitas Negeri Malang, Indonesia.

Article submitted 2021-01-09. Resubmitted 2021-02-23. Final acceptance 2021-02-24. Final version published as submitted by the authors. 